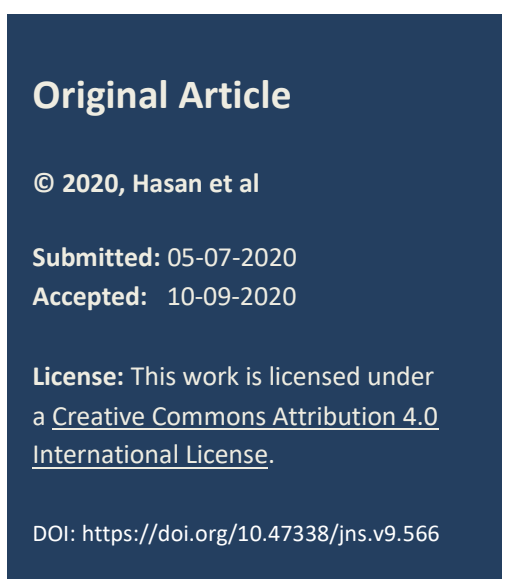

\title{
Duodenal atresia with absence of superior mesenteric artery and apple peel appearance of small gut: A case report
}

\author{
Samiul Hasan, ${ }^{*}$ Jiaul Reza, Fatema Sayeed
}

Division of Pediatric Surgery, Dhaka Shishu (Children) Hospital, Dhaka, Bangladesh.

Correspondence*: Dr. Md. Samiul Hasan, Assistant Professor, Division of Pediatric Surgery, Dhaka Shishu (Children) Hospital, Dhaka, E-mail: samiulo45@gmail.com

\section{KEYWORDS}

Duodenal atresia, Apple peel atresia, Bishop Koop enterostomy

\section{ABSTRACT}

Background: Though duodenal atresia is relatively common among intestinal atresias, its association with apple peel type of jejunoileal atresia and absent superior mesenteric artery (SMA) is very rare. This association contradicts the well-known embryo pathology of duodenal atresia and could be a management challenge.

Case presentation: A 4-day-old preterm male baby presented with bilious vomiting. The Xray abdomen showed a double bubble sign. Laparotomy revealed atresia of the 3rd part of the duodenum. The SMA was absent and the remaining small gut was short, narrow, and twisted around a narrow vascular pedicle arising from the marginal artery. We resected the most distal part of the dilated duodenum and made a wide end to side anastomosis with distal chimney stoma (Bishop Koop enterostomy). The baby did well in the postoperative period.

Conclusion: The surgical management of this rare entity was technically challenging. Bishop Koop enterostomy is a safe option when the primary anastomosis is not possible.

\section{INTRODUCTION}

Duodenal atresia is common among gastrointestinal atresias.[1] Failure of the recanalization during embryonic development is thought to be the cause that is different from the 'vascular accident' theory of atresia in other parts of the intestine.[1,2] In the most common form of duodenal atresia (more than $90 \%$ ), the obstruction is caused by a mucosal web. In the other two forms (less than 10\%), there presents a gap in continuity and/or in the mesentery. In all three types, the rest of the small gut is usually normal. Kimura's duodenoduodenostomy is the most preferred surgical procedure in duodenal atresia.[3] We describe an extremely rare association where duodenal atresia was associated with the absence of superior mesenteric artery and apple peel appearance of the small gut in a preterm baby. Only seven cases have been reported so far. This rare presentation reflects a vascular accident in the embryology of duodenal atresia and at the same time poses a tough challenge during the operative correction. $[4,5]$

\section{CASE REPORT}

A 4-day-old male neonate was referred from the special care baby unit because of bilious vomiting and nonpassage of meconium since birth. The baby was 3rd in birth order with gestational age of 34 weeks and a birth weight of $1.8 \mathrm{~kg}$. The antenatal ultrasound showed polyhydramnios. The rest of the antenatal period was uneventful.

At presentation, the baby was ill-looking, lethargic, and dehydrated with a capillary refill time (CRT) of $>3$ seconds. The upper abdomen was full and the nasogastric aspirate was bilious. Blood gas analysis at admission showed metabolic acidosis. The baby was kept in an incubator and the fluid resuscitation was started immediately with two normal saline boluses $(20 \mathrm{ml} / \mathrm{Kg})$. The triple intravenous antibiotics (Ceftazidime, Metronidazole, and Amikacin) were started. The baby was catheterized to monitor urine output. After fluid bolus, CRT was normal and metabolic acidosis was corrected. $10 \%$ glucose in $0.45 \%$ normal saline was started as maintenance fluid. 
After initial resuscitation, we performed an X-ray abdomen which showed a double bubble shadow. Echocardiography revealed a large ventricular septal defect (VSD). The baby was planned for laparotomy and revealed type III atresia on the 3rd part of the duodenum with a large mesenteric defect. The proximal duodenum was hugely dilated. We checked for the mesenteric attachment and found the whole root of the mesentery along with SMA was absent. The proximal jejunum was absent, and the remaining small gut was about $30 \mathrm{~cm}$ long, spiraled around a very narrow vascular pedicle arising in a retrograde fashion from the transverse mesocolon producing an apple peel appearance (Fig.1).

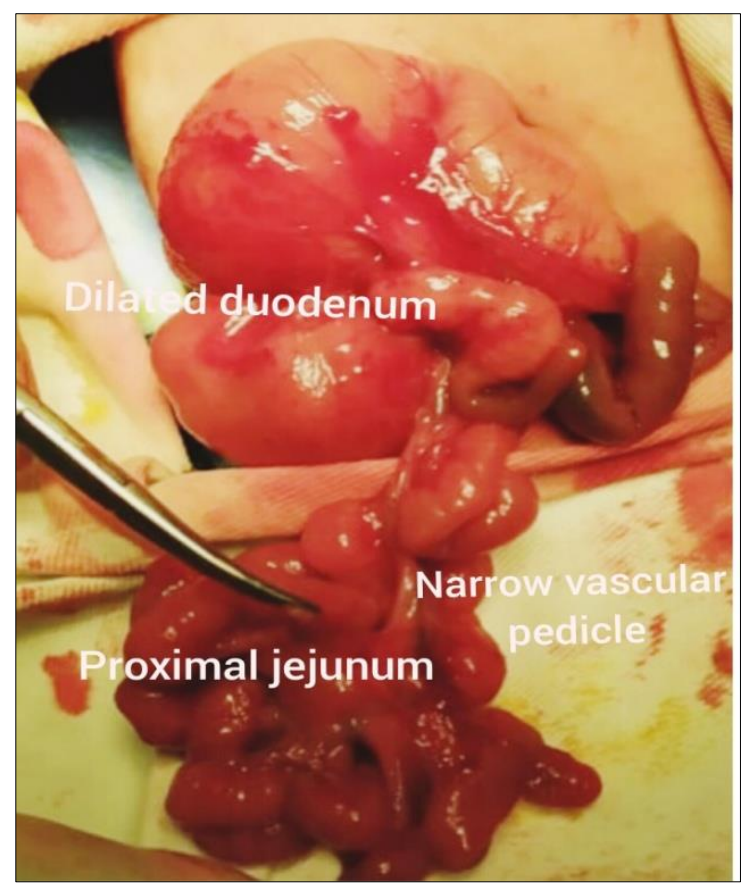

Figure 1: Showing Dilated duodenal and apple peel configuration of the small bowel

After confirming the distal patency, we tried to straighten the small gut but failed. We resected the most distal $2 \mathrm{~cm}$ of the duodenum and made an end to side anastomosis between the end of the duodenum and the ante-mesenteric border of the jejunum, $5 \mathrm{~cm}$ from its proximal end. The proximal end of the jejunum was then brought out as a stoma (Bishop Koop enterostomy). We left some degree of twisting of the small gut as it was not compromising the vascularity and the vascular pedicle was fixed along the medial border of the dilated duodenum to prevent further torsion.

The baby was kept nil per oral and on continuous nasogastric suctioning. Bowel movement started from the 3rdpostoperative day (POD), but nasogastric aspirate was still bilious. We started test feed on the 5thpostoperative day when stomal effluent was minimum. The baby tolerated oral feed well after 15th POD. Baby had a superficial wound infection which was managed conservatively. We discharged the baby with a referral to the pediatric cardiac surgery for VSD correction. The stoma shall be closed after 8 weeks, on adequate weight gain.

\section{DISCUSSION}

Apple peel atresia itself is a rare and severe variety of small intestinal atresia, constitutes only $5-10 \%$ cases. Atresia in this variety occurs high in the jejunum due to vascular accident during intrauterine life. Blood supply distal to the atresia is also abnormal, comes in a retrograde fashion from the ileocolic or inferior mesenteric artery, and the intestine spirals around the narrow vascular pedicle. Duodenal atresia on the other hand results from failure of recanalization during embryonic development. The co-existence of duodenal atresia and apple peel appearance of the small gut in the same patient is extremely rare. On perusal of the literature, we found only 7 cases reported in the literature. All were premature and having low birth weight (Table 1). $[2,4-8]$.

The pathogenesis of this rare association is still unclear. A vascular accident affecting the superior mesenteric artery in the late gestation might cause this presentation.[2,4] In an extremely rare event, apple peel atresia may present in association with ocular anomaly and microcephaly, known as Stromme syndrome.[5] In our patient, there was no such anomaly present. With the advancement of neonatal surgical and perioperative management, the outcome of the apple peel atresia has improved over the past decades. The adverse outcome is usually associated with prematurity and coexisting anomalies.[6,9] Our patient was premature and had a congenital heart defect (ventricular septal defect).

Tapering of the dilated duodenum \& primary anastomosis have been mentioned as an option. Tapering speeds up the establishment of peristalsis and reduces the duration of total parenteral nutrition (TPN) but leaves a long suture line.[2,4,5,9] We did Bishop Koop enterostomy in our patient. We found primary anastomosis very difficult even after tapering as the distal ileum was too narrow and twisted around the vascular pedicle. Bishop Koop enterostomy allows an adequate end to side anastomosis and maintains intestinal continuity. The ostomy acts as a vent to decompress the distal intestine if there is a delay in the establishment of function and thereby reduce the pressure on the anastomosis.[10] We felt difficulty in managing the spiral small gut. It was very prone to torsion due to a narrow vascular pedicle. We left the spiral configuration as such and fixed the vascular pedicle along the medial border of the duodenum to prevent future torsion. 
Table 1: Summary of the similar cases reported in the literature

\begin{tabular}{|c|c|c|c|c|c|c|}
\hline $\begin{array}{l}\text { Sr. } \\
\text { No }\end{array}$ & Author and Year & $\begin{array}{l}\text { Gestational } \\
\text { age } \& \text { birth } \\
\text { weight }\end{array}$ & Gender & Anomalies found & Surgery performed & Outcome \\
\hline 1 & $\begin{array}{l}\text { Weber \& Freeman } \\
\text { (1999) }\end{array}$ & $\begin{array}{l}36 \text { weeks } \\
2.1 \mathrm{Kg}\end{array}$ & $\mathrm{F}$ & $\begin{array}{l}\text { Annular pancreas, Absent } \\
3^{\text {rd } \&} 4^{\text {th }} \text { part of the } \\
\text { duodenum, proximal } \\
\text { jejunum and SMA, Apple } \\
\text { peel small gut, VSD, } \\
\text { Downs syndrome }\end{array}$ & $\begin{array}{l}\text { End to end duodenojejunal } \\
\text { anastomosis }\end{array}$ & Survived \\
\hline 2 & $\begin{array}{l}\text { Tatekawa et al. } \\
(2007)\end{array}$ & $\begin{array}{l}36 \text { weeks, } \\
2.1 \mathrm{Kg}\end{array}$ & $\mathrm{F}$ & $\begin{array}{l}\text { Duodenal membrane } \\
\text { atresia, Apple peel small } \\
\text { bowel, and multiple } \\
\text { intestinal atresias }\end{array}$ & $\begin{array}{l}\text { Side to side } \\
\text { Duodenoduodenostomy } \\
\text { and end to side } \\
\text { duodenoileostomy }\end{array}$ & Survived \\
\hline 3 & Ahmed et al. (2009) & $\begin{array}{l}34 \text { weeks, } \\
1.2 \mathrm{Kg}\end{array}$ & M & $\begin{array}{l}\text { Absent } 3^{\text {rd }} \& 4^{\text {th }} \text { part of } \\
\text { duodenum and SMA, Apple } \\
\text { peel small gut }\end{array}$ & $\begin{array}{l}\text { End to end } \\
\text { duodenojejunostomy }\end{array}$ & Died \\
\hline 4 & Patil et al. (2011) & $\begin{array}{l}33 \text { weeks, } \\
1.6 \mathrm{Kg}\end{array}$ & $\mathrm{F}$ & $\begin{array}{l}\text { Duodenal atresia, Apple } \\
\text { peel small gut, malrotation }\end{array}$ & Duodenojejunostomy & Died \\
\hline 5 & $\begin{array}{l}\text { Alnosair et al. } \\
(2014)\end{array}$ & $\begin{array}{l}31 \text { Weeks, } \\
1.4 \mathrm{Kg}\end{array}$ & $\mathrm{F}$ & $\begin{array}{l}\text { Duodenal atresia, Absent } \\
\text { SMA, Apple peel small gut }\end{array}$ & $\begin{array}{l}\text { End to end } \\
\text { duodenojejunostomy }\end{array}$ & Survived \\
\hline 6 & $\begin{array}{l}\text { Pathak \& Narula } \\
\text { (2016) }\end{array}$ & $\begin{array}{l}33 \mathrm{Weeks}, \\
1.3 \mathrm{Kg}\end{array}$ & $\begin{array}{c}\text { Not } \\
\text { mentione } \\
\mathrm{d}\end{array}$ & $\begin{array}{l}\text { Duodenal atresia, Apple } \\
\text { peel small bowel }\end{array}$ & $\begin{array}{l}\text { End to oblique } \\
\text { duodenojejunostomy }\end{array}$ & Survived \\
\hline 7 & Sasa et al. (2016) & $\begin{array}{l}29 \text { Weeks, } \\
1.2 \mathrm{Kg}\end{array}$ & M & $\begin{array}{l}\text { Duodenal atresia, Absent } \\
\text { SMA, Apple peel small } \\
\text { bowel }\end{array}$ & $\begin{array}{l}\text { Resection of jejunum and } \\
\text { end to end } \\
\text { duodenoileostomy }\end{array}$ & Died \\
\hline
\end{tabular}

Bishop Koop enterostomy is gaining popularity in the management of severe jejunoileal atresia. It reduces re-operation rate, TPN dependency in the postoperative period and improves surgical and nutritional outcomes in patients with severe jejunoileal atresia. The only problem is it requires a second operation to close the stoma. $[10,11]$

Though the long-term outcome of apple peel atresia is fairly good, our patient might experience a short bowel syndrome and malnutrition due to short length of the remaining gut. The presence of large VSD and prematurity could further complicate the situation. The co-occurrence of duodenal atresia and apple peel appearance of small gut is extremely rare.

\section{REFERENCES}

1. Kumar P, Kumar C, Pandey PR, Sarin YK. Congenital duodenal obstruction in neonates: Over 13 years' experience from a single centre. J Neonatal Surg. 2016; $5: 50$.

2. Saša RV, Ranko L, Snezana C, Lidija B, Djordje S. Duodenal atresia with apple-peel configuration of the ileum and absent superior mesenteric artery. BMC Pediatrics. 2016;16:150

3. Applebaum $\mathrm{H}$, Sydorak R. Duodenal atresia and stenosis- annular pancreas. In: Coran AG, Adzick NS, Krummel TM, Laberge JM, Shamberger RC, CaldamoneAA, editors. Pediatric Surgery. 7th edition. Philadelphia: Elsevier Saunders; 2012. p. 1051-7.

4. Pathak M, Narula D. A case of duodenal atresia with apple peel appearance: Challenging the current embryology. J Clin Neonatol. 2014; 3: 112-4.
Prematurity and other coexisting anomalies should be managed meticulously for improved surgical outcomes. Bishop Koop enterostomy could be considered as an appropriate surgical option.

Acknowledgements: Nil

Conflict of Interest: Authors have no conflict of interest.

Source of Support: Nil

Consent to Publication: Author(s) declared taking informed written consent for the publication of clinical photographs/material (if any used), from the legal guardian of the patient with an understanding that every effort will be made to conceal the identity of the patient, however it cannot be guaranteed.

Author Contributions: Author(s) declared to fulfil authorship criteria as devised by ICMJE and approved the final version.

5. Alnosair AA, Naga AI, Abdulla MR, Al-Salem AH. Congenital duodenal atresia with 'apple-peel configuration' of the small intestines and absent superior mesenteric artery: A case report and review of literature. J Ped Surg Case Rep. 2014; 2:215-8.

6. Weber DM, Freeman NV. Duodenojejunal atresia with apple peel configuration of the ileum and absent superior mesenteric artery: observations on pathogenesis. J Pediatr Surg. 1999; 34:1427e9.

7. Tatekawa Y, Kanehiro H, Nakajima Y. Duodenal atresia associated with "apple peel" small bowel without deletion of fibroblast growth factor-10 or fibroblast growth factor receptor 2IIIb: report of a case. Surg Today. 2007; 37:430-3.

8. Ahmad A, Sarda D, Joshi P, Kothari P. Duodenal atresia with 'apple-peel configuration' of the ileum and absent 
superior mesenteric artery: a rare presentation. Afr $\mathrm{J}$ Paediatr Surg. 2009; 6:120e1.

9. Zhu H, Gao R, Alganabi M, Dong K, Ganji N, Xiao X, et al. Long-term surgical outcomes of apple-peel atresia. J Pediatr Surg. 2019; 54:2503-8.

10. Hasan MS, Rahman A, Huq U, Ferdous KN, Ali MA. Bishop Koop conversion of temporary stoma can be an option to establish gut continuity early when primary anastomosis is not safe. World J Pediatr Surg., 2019; 2:e000025.

11. Peng $\mathrm{Y}$, Zheng $\mathrm{H}$, Zhang $\mathrm{H}$, He Q, Wang $Z$, Zhong W, et al. Comparison of outcomes following three surgical techniques for patients with severe jejunoileal atresia, Gastroenterology Report. 2019; 7:444-8. 